\title{
S. aureus Biofilm Protein Expression Linked to Antimicrobial Resistance: A Proteomic Study
}

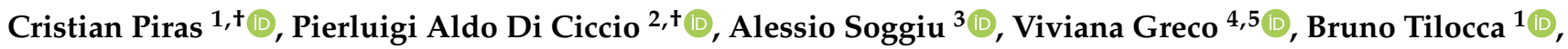 \\ Nicola Costanzo ${ }^{1}$, Carlotta Ceniti ${ }^{1}$, Andrea Urbani ${ }^{4,5}$, Luigi Bonizzi ${ }^{3}$, Adriana Ianieri ${ }^{6}$ and Paola Roncada ${ }^{1, * \mathbb{C}}$
}

1 Department of Health Sciences, University "Magna Græcia" of Catanzaro, Campus Universitario "S. Venuta", Viale Europa, I-88100 Catanzaro, Italy; c.piras@unicz.it (C.P.); tilocca@unicz.it (B.T.); costanzo.nic@unicz.it (N.C.); ceniti@unicz.it (C.C.)

2 Department of Veterinary Sciences, University of Torino, Largo Paolo Braccini 2, Grugliasco, 10095 Torino, Italy; pierluigialdo.diciccio@unito.it

3 Surgical and Dental Sciences-One Health Unit, Department of Biomedical, University of Milano, Via Celoria 10, 20133 Milano, Italy; alessio.soggiu@unimi.it (A.S.); luigi.bonizzi@unimi.it (L.B.)

4 Department of Basic Biotechnological Sciences, Intensivological and Perioperative Clinics, Università Cattolica del Sacro Cuore, Largo Francesco Vito 1, 00168 Roma, Italy; viviana.greco@unicatt.it (V.G.); andrea.urbani@unicatt.it (A.U.)

5 Molecular and Genomic Diagnostics Unit, Fondazione Policlinico Universitario Agostino Gemelli IRCCS, Largo A. Gemelli 8, 00168 Roma, Italy

6 Deparment of Food and Drug, University of Parma, Parco Area delle Scienze 27A, 43124 Parma, Italy; adriana.ianieri@unipr.it

* Correspondence: roncada@unicz.it

+ Equal contribution.

updates

Citation: Piras, C.; Di Ciccio, P.A.; Soggiu, A.; Greco, V.; Tilocca, B.; Costanzo, N.; Ceniti, C.; Urbani, A.; Bonizzi, L.; Ianieri, A.; et al. S. aureus Biofilm Protein Expression Linked to Antimicrobial Resistance: A Proteomic Study. Animals 2021, 11, 966. https://doi.org/10.3390/ ani11040966

Academic Editor: Amit Vikram

Received: 3 March 2021

Accepted: 24 March 2021

Published: 31 March 2021

Publisher's Note: MDPI stays neutral with regard to jurisdictional claims in published maps and institutional affiliations.

Copyright: (c) 2021 by the authors. Licensee MDPI, Basel, Switzerland. This article is an open access article distributed under the terms and conditions of the Creative Commons Attribution (CC BY) license (https:/ / creativecommons.org/licenses/by/ $4.0 /)$.
Simple Summary: Biofilm formation represents one of the most effective forms of bacterial persistence in surfaces where nutrients are available or in the tissues of living hosts as humans or animals. Such persistence is due to the high rate of antimicrobial resistance of this shell conformation. It often represents a burden when the pathogen colonizes niches from where it is not removable such as food facilities, farm facilities or parts of living organisms. In this study, we investigated biofilm formation mechanisms and enhanced antimicrobial resistance of 6 different $S$. aureus strains. The detected mechanisms were primarily related to the control of catabolites, the production of proteins with moonlighting activities and the detoxification of compounds with antimicrobial activities (i.e., alcohol). Glycolysis and aerobic metabolisms were found to be less active in the biofilm conformation. Consequently, less $\mathrm{H}_{2} \mathrm{O}_{2}$ production from aerobic metabolism was translated into a measurable under-representation of catalase protein.

Abstract: Antimicrobial resistance (AMR) represents one of the most critical challenges that humanity will face in the following years. In this context, a "One Health" approach with an integrated multidisciplinary effort involving humans, animals and their surrounding environment is needed to tackle the spread of AMR. One of the most common ways for bacteria to live is to adhere to surfaces and form biofilms. Staphylococcus aureus (S. aureus) can form biofilm on most surfaces and in a wide heterogeneity of environmental conditions. The biofilm guarantees the survival of the $S$. aureus in harsh environmental conditions and represents an issue for the food industry and animal production. The identification and characterization of biofilm-related proteins may provide interesting insights into biofilm formation mechanisms in S. aureus. In this regard, the aims of this study were: (i) to use proteomics to compare proteomes of S. aureus growing in planktonic and biofilm forms in order to investigate the common features of biofilm formation properties of different strains; (ii) to identify specific biofilm mechanisms that may be involved in AMR. The proteomic analysis showed 14 differentially expressed proteins among biofilm and planktonic forms of $S$. aureus. Moreover, three proteins, such as alcohol dehydrogenase, ATP-dependent 6-phosphofructokinase, and fructose-bisphosphate aldolase, were only differentially expressed in strains classified as high biofilm producers. Differentially regulated catabolites metabolisms and the switch to lower oxygenrelated metabolisms were related to the sessile conformation analyzed. 
Keywords: Staphylococcus aureus; planktonic cells; biofilm; proteomics; food safety; antimicrobial resistance

\section{Introduction}

Humanity is already facing a challenge related to antimicrobial resistance (AMR). Such a burden will become worse due to the massive use of antimicrobials such as alcohol-based products for hands and workplaces sanitization necessary to mitigate the transmission of coronavirus disease 2019 (COVID-19). These key precautions may create an ecological pressure on microorganisms and contribute to the emergence of AMR in microbial populations that can colonize human body and the environment.

The use of biocides in the environment (such as farms and food industries) has already created a phenomenon known as AMR cross-resistance [1-3]. Biofilm formation contributes to enhance AMR resistance by physical and biochemical means [4]. A biofilm is defined as "a microbially derived sessile community characterized by cells that are irreversibly attached to a substrate or interface or to each other, are embedded in an autoproduced matrix of extracellular polymeric substances (which is composed of protein, DNA and polysaccharide) and exhibit an altered phenotype with respect to growth rate and gene transcription" [5]. It is well known that bacteria growing as biofilms might be physiologically distinct from the same bacteria growing as free-swimming planktonic cells $[6,7]$.

Briefly, biofilms allow bacteria to better resist harsh environmental conditions [8]. Such a conformation can be found everywhere where there is a source of nutrients such as in the food-processing environment or zootechnical industry (food-processing equipment, milk collection and storage facilities) [9]. Biofilms-enhanced resistance to disinfectants/antimicrobials/antibiotics represents a threat for food industries and farms [10]. The biofilm, in fact, protects the bacteria from detaching by cleaning agents and from being killed by disinfectants [11]. However, biofilm protection mechanisms appear to be different from those responsible for resistance to conventional antibiotics [12]. First, the extracellular polymeric substances (EPS) matrix delays or prevents antimicrobial action, either by limiting disinfectants diffusion or by chemical interaction/inactivation with proteins and extracellular polysaccharides [13]. Other factors can play a role in this feature, such as the bacterial growth rate, the heterogeneity within the biofilm, the general stress response, quorum sensing mechanisms, the induction of a certain biofilm phenotype and the over-expression of efflux pumps [14]. In addition, biofilm activities include the upregulation of virulence factors and secretion of extracellular polymers [15]. Horizontal gene transfer plays an important role in AMR. The small intra-cellular distance typical of biofilms facilitates the spread of resistance genes and generates the presence of extracellular DNA in the biofilm matrix [16].

Among bacteria, Staphylococcus aureus (S. aureus) is able to form biofilm on most surfaces and under almost all the environmental conditions found in food industries [17]. It is a commensal and opportunistic pathogen and under certain conditions, may cause a wide range of infectious diseases such as skin infections, bacteremia, endocarditis, pneumonia and food poisoning. S. aureus biofilm mode of growth is regulated by complex genetic factors and can produce at least two different types of biofilm: ica operon-dependent (i.e., promoted by the ica operon) and ica operon-independent [17]. A study carried out by Resch et al. (2005) identified more than 160 genes that were significantly over-expressed during biofilm growth conditions. Those genes encoded for binding factors, polysaccharide intracellular adhesion (PIA) and peptidoglycan modeling factors [7]. Additionally, many proteins have been implicated as important components in cellular adhesion and biofilm matrix development [18]. These include surface-associated proteins (protein A), fibrinogenbinding proteins (FnBPA and FnBPB), biofilm-associated protein (Bap) and clumping factor B (ClfB). 
Considering the concerns for food safety associated with $S$. aureus biofilms and the high cost of managing this issue in the food industry, a better knowledge of the mechanisms involved in S. aureus biofilm growth mode is essential. To date, several studies have focused on pathogenicity and only a few have addressed differences in protein expression of $S$. aureus due to biofilm formation $[19,20]$. The identification and characterization of proteins linked with biofilm could provide interesting insights on the mechanism and/or process of biofilm formation in $S$. aureus.

According to this premise, the aims of this study were: (i) to compare proteomes of $S$. aureus growing in planktonic and biofilm forms, in order to investigate the common features of biofilm formation properties of six different strains; and (ii) to identify possible biofilm mechanisms that may be involved in AMR. The employment of 6 different strains will help with the comprehension of biofilm formation mechanisms more representative of the $S$. aureus species rather than be focused on mechanisms typical of a single strain.

\section{Materials and Methods}

\subsection{Bacterial Strains}

A total of six biofilm-forming S. aureus strains were analyzed in this study. In details, three S. aureus reference strains (ATCC 35556, ATCC 12600, ATCC 29213) and three foodrelated isolates (wild-types) were used in the experiment. The food related-strains were isolated from food (n.1) and food handlers (n.2), respectively.

Stock cultures were stored at $-80{ }^{\circ} \mathrm{C}$. All strains were incubated for $24 \mathrm{~h}$ at $37{ }^{\circ} \mathrm{C}$ in tryptone soy broth (TSB, Oxoid S.p.A., Milan, Italy) before each experiment. All these strains have been grown both in the planktonic and in the sessile form (biofilm cultures) and analyzed through 2D electrophoresis coupled with matrix-assisted laser desorption/ionization time-of-flight mass spectrometry (MALDI-TOF MS).

The sessile (biofilm cultures) and planktonic cells were prepared as follows:

- Biofilm cultures

The ability of $S$. aureus isolates to produce biofilms was determined according to the protocol described by Di Ciccio et al., 2015 [21]. In all cases, all experiments were repeated in triplicate. Briefly, polystyrene tissue culture plates (6 wells- $961 \mathrm{~mm}^{2}$ ) were used as substratum for biofilm formation at $37^{\circ} \mathrm{C}$. Cultures of $S$. aureus were prepared, from overnight tryptone soy agar (TSA, Oxoid S.p.A., Milan, Italy) growth, in TSB by incubating at selected temperature: $37^{\circ} \mathrm{C}$. Cultures were then washed three times with sterile phosphate-buffered saline (PBS; pH 7.3) (Sigma-Aldrich S.r.l., Milan, Italy) and diluted with fresh TSB to reach a concentration of about $10^{8}$ colony-forming units (CFU) $\mathrm{mL}^{-1}$ by reading the optical density (OD) level at $550 \mathrm{~nm}$ (UV Mini-1240-Shimadzu, Long Beach, CA, USA). Three milliliters $(\mathrm{ml})$ of the standardized inoculum were then added to polystyrene tissue culture plates (well-35 $\mathrm{mm}$ diameter). Samples were then incubated at $37^{\circ} \mathrm{C}$. After $24 \mathrm{~h}$ incubation, non-adherent cells were removed by washing each well three times with sterile PBS. After adding sterile PBS $(3 \mathrm{~mL})$, biofilm in wells was dislodged mechanically by scraping vigorously using a sterile cell-scraper. Finally, the cells were harvested by centrifugation (4000 rpm, $10 \mathrm{~min} ., 4^{\circ} \mathrm{C}$, Beckman, J2-MC, centrifuge). The resulting pellets, washed and resuspended in sterile PBS, were centrifuged again (4000 rpm, $10 \mathrm{~min} .4^{\circ} \mathrm{C}$ ). The cells were washed several times and pelleted by five centrifugations. Finally, the supernatant was removed and the pellet from the biofilm cultures grown was stored at $-80^{\circ} \mathrm{C}$ until use for proteomic studies (the pellets from the biofilm cultures had a weight of $50 \mathrm{mg}$ ).

- Planktonic cells

S. aureus reference strains (ATCC 35556, ATCC 12600, ATCC 29213) and food-related isolates $S$. aureus $(281,402,184)$ were used. An overnight culture was created by inoculating a colony of $S$. aureus into $5 \mathrm{~mL}$ of TSB for $24 \mathrm{~h}$ at $37^{\circ} \mathrm{C}$. After incubation, the $S$. aureus culture was centrifuged for $10 \mathrm{~min}$ at $4000 \mathrm{rpm}, 4^{\circ} \mathrm{C}$. The supernatant was then replaced 
with sterile PBS, and pellet was resuspended by thoroughly mixing with pipette. The cells were washed several times and pelleted by five centrifugations (4000 rpm, $10 \mathrm{~min}, 4{ }^{\circ} \mathrm{C}$ ). Finally, the supernatant was removed and the pellet from the overnight cultures grown was stored at $-80^{\circ} \mathrm{C}$ until use for proteomic studies (the pellets from the planktonic cultures had weights: $50 \mathrm{mg}$ ).

\subsection{Proteomic Analysis}

- Protein Extraction and 2-Dimensional Electrophoresis (2-DE)

We diluted 50 milligrams of cellular pellet of the different $S$. aureus strains in $700 \mu \mathrm{L}$ of 2DE buffer containing $7 \mathrm{M}$ urea, $2 \mathrm{M}$ thiourea, 4\% CHAPS, 1\% DTT, and protease inhibitors (GE-Healthcare) according to manufacturer instructions.

To ensure the complete disruption of the collected bacterial cells, the samples were processed with 6 cycles of 1-min bead beating interspersed by a cycle of centrifuge. For this purpose, into the sample was added the same amount (1:1 v/w) of $0.1 \mathrm{~mm}$ zyrcouniumsilica beads ( $300 \mu \mathrm{g}$ beads added to $300 \mu \mathrm{L}$ of buffer + the volume of the pellet). The bead beating cycle was conducted at $4000 \mathrm{rpm}$ for $1 \mathrm{~min}$ with the purpose to avoid overheating. Then, the samples were centrifuged at $12,000 \times g$ for $5 \mathrm{~min}$ at $4{ }^{\circ} \mathrm{C}$ in order to chill and disperse the foam. This operation was repeated 6 times. After the 6 th cycle, samples were centrifuged for $20 \mathrm{~min}$ and the supernatant was stored in another tube for subsequent proteomics analysis.

Two-dimensional (2D) electrophoresis was run in all samples: 100 micrograms of protein were loaded on a $7 \mathrm{~cm}$ strip through active rehydration performed overnight at $50 \mathrm{~V}$ in a buffer containing $7 \mathrm{M}$ urea, $2 \mathrm{M}$ thiourea, 2\% CHAPS, $0.5 \%$ ampholytes 3-10 Amersham, and $26 \mathrm{mM}$ DTT. For isoelectric focusing (IEF), the following protocol was applied: $100 \mathrm{~V} / 1 \mathrm{~h}$ linear, $250 \mathrm{~V} / 2 \mathrm{~h}$ linear, $4000 \mathrm{~V} / 5 \mathrm{~h}$ linear, $4000 \mathrm{~V}$ step $/ 50,000$ total volt-hours (VhT), using a protean IEF platform.

Once the final amount of VhT was reached, immobilized $\mathrm{pH}$ gradient (IPG) strips were frozen up to the next step or directly equilibrated in two steps of 15 min under gentle stirring. The first step of equilibration was performed in buffer (6 M UREA, 2\% SDS, $0.05 \mathrm{M}$ Tris- $\mathrm{HCl} \mathrm{pH} 8.8,20 \%$ glycerol) supplemented with 1\% DTT $w / v$ and the second step was performed in a buffer with the addition of $2.5 \% \mathrm{w} / \mathrm{v}$ iodoacetamide. The IPG strips were put in a $12 \%$ home-made acrylamide gel and IEF run under constant amperage of $15 \mathrm{~mA}$ per gel, until the bromophenol blue (BFB) reached the front. The gels were then eliminated from the plates, washed three times with double-distilled water and spotted overnight (ON) with Coomassie Brilliant Blue.

Using an Imagescanner III (GE Healthcare) the gels were digitalized. The image analysis was performed using SameSpots software (Version 4.5, Nonlinear Dynamics U.K.). All imported images were checked for quality (saturation, ending) and spots, with a $p$-value lower than 0.05 , were manually excised for subsequent mass spectrometry (MS) analysis and protein identification. If the MALDI MS/MS identification was obtained with a MASCOT score higher than 40, the protein was analyzed via GO for the comprehension of its function/role.

- Protein Identification by Matrix-Assisted Laser Desorption/Ionization Time-of-Flight Mass Spectrometry (MALDI-TOF/TOF MS) Analysis

Protein identification was performed according to previous studies [22,23].

Briefly, after different steps of dehydration, reduction and alkylation, the excided single spots were digested with a solution of $0.01 \mu \mathrm{g} / \mu \mathrm{L}$ of porcine trypsin (Promega, Madison, WI, USA) at $37{ }^{\circ} \mathrm{C}$ o.n., and peptides were concentrated using C18 ZipTip (Millipore, Bedford, MA, USA). they were then co-crystallized with a solution of $\alpha$ ciano4-hydroxycinnamic acid and spotted on a Ground Steel plate (Bruker-Daltonics, Bremen, Germany).

The MS analysis was performed on a Ultraflex III MALDI-TOF/TOF spectrometer (Bruker-Daltonics) in positive reflectron mode. 
External calibration was performed using the standard peptide mixture calibration (m/z: 1046.5418, 1296.6848, 1347.7354, 1619.8223, 2093.0862, 2465.1983, 3147.4710; BrukerDaltonics).

FlexAnalysis 3.3 software (Bruker-Daltonics) was used for the selection of the monoisotopic peptide masses of each mass spectra. After an internal calibration on autolysis peaks of porcine trypsin (m/z: 842.509 and 2211.104) and exclusion of contaminant ions (known matrix and human keratin peaks), the created peak lists were analyzed by MASCOT v.2.4.1 algorithm (www.matrixscience.com, accessed on 23 March 2021) searching against SwissProt 2021_database restricted to Firmicutes and Staphylococcus aureus (11,196 sequences) taxonomy.

The parameters used for database search are the following: carbamidomethylation of cysteines and oxidation on methionine as fixed and variable modifications respectively; one missed cleavage site allowed for trypsin; 70 ppm as maximal tolerance.

Mascot protein scores greater than 50 were considered significant $(p<0.05)$ for protein identification assignment.

To confirm the identifications, MS/MS spectra were also acquired by switching the instrument in LIFT mode with $4-8 \times 10^{3}$ laser shots. For the fragmentation, precursor ions were manually selected, and the precursor mass window was automatically set. Spectra baseline subtraction, smoothing (Savitsky-Golay) and centroiding were operated using Flex-Analysis 3.3 software.

The parameters used for the database search are the following: carbamidomethylation of cysteines and oxidation on methionine as fixed and variable modifications respectively; one missed cleavage; $50 \mathrm{ppm}$ and 0 . $5 \mathrm{Da}$ as mass tolerance for precursor ions and for fragments respectively. The taxonomy was restricted to Staphylococcus aureus (10,227 sequences).

The confidence interval for protein identification was set to $95 \%(p<0.05)$ and only peptides with an individual ion score above the identity threshold were considered correctly identified.

\section{Results}

The proteomic analysis was performed in order to discover the mechanisms of biofilm formation common to all analyzed $S$. aureus strains. Six different strains with different biofilm formation indexes were analyzed in the planktonic form and the biofilm form. For each strain, biofilm formation, expressed as BPI, was calculated as follows: “BPI $=\left[\mathrm{OD}_{\text {mean biofilm }}\right.$ surface $\left.\left(\mathrm{mm}^{2}\right)^{-1}\right] \times 1000^{\prime}$. All isolates were defined in different categories (weak, moderate or strong producers) on the basis of their BPIs values (Table 1).

Table 1. Biofilm formation index (BPI) of S. aureus strains on polystyrene at $37^{\circ}$ included in this study.

\begin{tabular}{ccc}
\hline Strains & Source & BPI \\
\hline A-S. aureus ATCC n.35556 & ATCC n.35556 & 0.758 \\
B-S. aureus ATCC n.12600 & ATCC n.12600 & 0.405 \\
C-S. aureus n.281 & Food & 1.019 \\
D-S. aureus n.402 & Food-handler & 0.311 \\
E-S. aureus n.184 & Food-handler & 0.290 \\
F-S. aureus ATCC 29213 & ATCC n.29213 & 0.260 \\
\hline
\end{tabular}

The analyzed strains included: S. aureus ATCC 35556, already described as a strong biofilm producer [24,25]; S. aureus ATCC 12600, classified as moderate biofilm producer [21]; three food isolates of $S$. aureus classified as strong (281), moderate (402) and weak biofilm producer (184); S. aureus ATCC 29213 measured as weak biofilm producer. BPI on polystyrene at $37{ }^{\circ} \mathrm{C}$ was used as the measure for all the experimental procedures in this work. All the strains with BPI below 0.300 were considered weak biofilm producers. In these cases, the biofilm layer was phenotypically barely visible and not stable in its structure. Such a phenotype was confirmed by the extremely low BPI below 300. For 
this reason, four strains (A, B, C and D) were considered as part of the moderate/high biofilm-producing group, while the remaining two (E and $\mathrm{F}$ ) showed a phenotype closer to the low/non-forming biofilm group.

Proteomics analysis was carried out to compare the sessile versus the planktonic phenotype; however, a separated analysis was performed, including only the moderated to strong biofilm producers. The differentially represented proteins were chosen according to the Progenesis SameSpots provided analysis of variance (ANOVA) $p$-value. The topmost significant ones were chosen to be analyzed via MALDI-TOF MS/MS peptide mass fingerprinting (PMF) and peptide fragment fingerprinting (PFF) if necessary. Of the chosen spots, only the ones successfully identified with a MASCOT score higher than 40 were considered for subsequent Gene Ontology (GO), metabolism and pathway analysis.

As reported in Table 2, 14 proteins were differentially expressed among S. aureus planktonic and sessile groups. Of these, 11 were differentially expressed when considering all the strains together with a $p$-value $\leq 0.05$ (column: regulation in planktonic vs. sessile). Alcohol dehydrogenase, ATP-dependent 6-phosphofructokinase and Fructose-bisphosphate aldolase differential expression were significant for the medium/high biofilm-forming sub-group (high biofilm producers' column). This classification was done according to the observation of the datasets that clearly showed how the representation trend of some of the differentially expressed proteins was clearly not following the same path in the weak biofilm forming strains. As previously mentioned, this was the case for alcohol dehydrogenase, ATP-dependent 6-phosphofructokinase and fructose-bisphosphate aldolase.

If considering the entirety of the differentially regulated proteins, five were found to be over-represented in the sessile versus planktonic group, and 9 proteins were found to be under-represented. This low number of detected proteins might be due to the high heterogeneity of the different strain analyzed. Three of the five over-represented proteins were involved in carbon metabolism or in stress response. Interestingly, alcohol dehydrogenase and $30 \mathrm{~s}$ ribosomal proteins are involved in antimicrobials resistance mechanisms, i.e., detoxification.

On the other hand, under-represented proteins such as 2,3-bisphosphoglyceratedependent phosphoglycerate mutase, alkyl hydroperoxide reductase subunit C, ATPdependent 6-phosphofructokinase, catalase etc. were mostly involved in energy and oxygen-related metabolism.

All data are shown in Table 2 and the image of the differentially represented proteins is shown in Figure 1a. For each protein, it is represented the related figure from the image analysis software. Table 2 indicates the $p$-values obtained from the built-in ANOVA test of the Progenesis SameSpots software. For each protein it is provided with the UNIPROT name and accession number (first two columns of the table); the SameSpots coding number, which represents the code provided by the image analysis software; the Mascot score identification obtained by the combined MALDI peptide mass fingerprint together with the peptide fragment fingerprint for the MS/MS identification; the number of matched peptides and the mascot score; and the ANOVA $p$-value obtained by comparing the planktonic and sessile form of all strains and just moderate/high biofilm producers (last column, the values of normalized volume for each spot are provided in Supplementary Materials, Table S1). 
Table 2. List of differentially represented proteins among the six different strains analyzed under planktonic and biofilm conditions. As in the last two columns, the analysis was performed, including all the analyzed strains and, subsequently, excluding the low biofilm producers (last column). OS= organism name. Every significant $p$-value (lower than 0.05 ) is printed in bold.

\begin{tabular}{|c|c|c|c|c|c|c|c|c|}
\hline $\begin{array}{l}\text { Uniprot } \\
\text { Name/Accession } \\
\text { Number }\end{array}$ & $\begin{array}{l}\text { Uniprot } \\
\text { Name }\end{array}$ & $\begin{array}{l}\text { SameSpots } \\
\text { Coding } \\
\text { Number }\end{array}$ & Protein Name & $\begin{array}{c}\text { Mascot } \\
\text { Score }\end{array}$ & $\begin{array}{l}\text { Sequence } \\
\text { Coverage } \\
\quad(\%)\end{array}$ & $\begin{array}{l}\text { N of } \\
\text { Matched } \\
\text { Peptides }\end{array}$ & $\begin{array}{l}\text { Regulation } \\
\text { in Sessile vs. } \\
\text { Planktonic }\end{array}$ & $\begin{array}{l}\text { High Biofilm } \\
\text { Producers } \\
\text { (Sessile vs. } \\
\text { Planktonic) }\end{array}$ \\
\hline Q2FJ31 & ADH_STAA3 & 820 & alcohol dehydrogenase & 66 & 35 & $9 / 59$ & $\uparrow 0.070$ & $\uparrow 0.018$ \\
\hline A7X656 & GPMA_STAA1 & 824 & $\begin{array}{c}\text { 2,3-bisphosphoglycerate- } \\
\text { dependent phosphoglycerate } \\
\text { mutase OS = Staphylococcus } \\
\text { aureus }\end{array}$ & 116 & 51 & $11 / 52$ & $\downarrow 0.001$ & $\downarrow 0.016$ \\
\hline $\mathrm{P} 0 \mathrm{~A} 0 \mathrm{H} 0$ & RS12_STAA8 & 836 & $30 \mathrm{~S}$ ribosomal protein S12 & 68 & 37 & $4 / 45$ & $\uparrow 0.026$ & 0.135 \\
\hline Q2FJN4 & AHPC_STAA3 & 838 & $\begin{array}{c}\text { Alkyl hydroperoxide reductase } \\
\text { subunit C OS = Staphylococcus } \\
\text { aureus }\end{array}$ & 67 & 39 & $6 / 31$ & $\downarrow 0.028$ & 0.137 \\
\hline A6U2G5 & PFKA_STAA2 & 840 & $\begin{array}{c}\text { ATP-dependent } \\
\text { 6-phosphofructokinase OS = } \\
\text { Staphylococcus aureus }\end{array}$ & 121 & 35 & $11 / 31$ & $\downarrow 0.084$ & $\downarrow 0.007$ \\
\hline A7WZR9 & CLPP_STAA1 & 842 & $\begin{array}{l}\text { ATP-dependent Clp protease } \\
\text { proteolytic subunit OS = } \\
\text { Staphylococcus aureus }\end{array}$ & 76 & 30 & $9 / 23$ & $\downarrow 0.008$ & 0.084 \\
\hline Q5HF38 & CCPA_STAAC & 845 & $\begin{array}{l}\text { Catabolite control protein A OS } \\
=\text { Staphylococcus aureus }\end{array}$ & 76 & 26 & $9 / 35$ & $\uparrow 0.001$ & $\uparrow 0.004$ \\
\hline Q9L4S1 & CATA_STAAU & 846 & $\begin{array}{c}\text { Catalase OS }=\text { Staphylococcus } \\
\text { aureus } \mathrm{GN}=\text { katA PE }=3 \mathrm{SV}=1\end{array}$ & 40 & 16 & & $\downarrow 0.041$ & $\downarrow 0.041$ \\
\hline Q9L4S1 & CATA_STAAU & 848 & $\begin{array}{c}\text { Catalase OS }=\text { Staphylococcus } \\
\text { aureus } \mathrm{GN}=\text { katA PE }=3 \mathrm{SV}=1\end{array}$ & 68 & 30 & $6 / 40$ & $\downarrow 0.021$ & $\downarrow 0.027$ \\
\hline Q9L4S1 & CATA_STAAU & 851 & $\begin{array}{c}\text { Catalase OS }=\text { Staphylococcus } \\
\text { aureus } \mathrm{GN}=\text { katA } \mathrm{PE}=3 \mathrm{SV}=1\end{array}$ & 98 & 47 & $11 / 40$ & $\downarrow 0.012$ & $\downarrow 0.004$ \\
\hline Q2FDQ4 & ALF1_STAA3 & 853 & $\begin{array}{c}\text { Fructose-bisphosphate aldolase } \\
\text { class } 1 \text { OS = Staphylococcus } \\
\text { aureus }\end{array}$ & 112 & 40 & $17 / 67$ & $\uparrow 0.096$ & $\uparrow 0.0002$ \\
\hline Q2YSZ4 & GCSPB_STAAB & 855 & $\begin{array}{c}\text { Probable glycine } \\
\text { dehydrogenase } \\
\text { (decarboxylating) subunit } 2 \text { OS } \\
\text { = Staphylococcus aureus } \\
\text { Probable GTP-binding protein }\end{array}$ & 68 & 26 & $9 / 50$ & $\downarrow 0.037$ & $\downarrow 0.013$ \\
\hline A7X395 & ENGB_STAA1 & 856 & $\begin{aligned} \text { EngB OS }= & \text { Staphylococcus aureus } \\
& \_12042016\end{aligned}$ & 68 & 16 & $4 / 16$ & $\downarrow 0.007$ & 0.060 \\
\hline Q7A551 & Y1532_STAAN & 858 & $\begin{array}{c}\text { putative universal stress protein } \\
\text { SA153 (782) } \\
\text { OS = Staphylococcus aureus }\end{array}$ & 86 & 36 & $6 / 35$ & $\uparrow 0.010$ & 0.094 \\
\hline
\end{tabular}

Figure 1a provides a graphic representation of the Coomassie Brilliant Blue stained entire proteins as detected by the image analysis software. The top four rows show high and moderate biofilm producers' spots, while the two rows at the bottom indicate the low biofilm producers.

Figure $1 \mathrm{~b}$ shows the graphic representation of the most relevant differentially regulated proteins and metabolisms among the two analyzed S. aureus phenotypes. Biological functions were manually checked after each GO search and subsequently reported in the scheme in Figure 1b. 
a

Over-represented proteins

Under-represented proteins

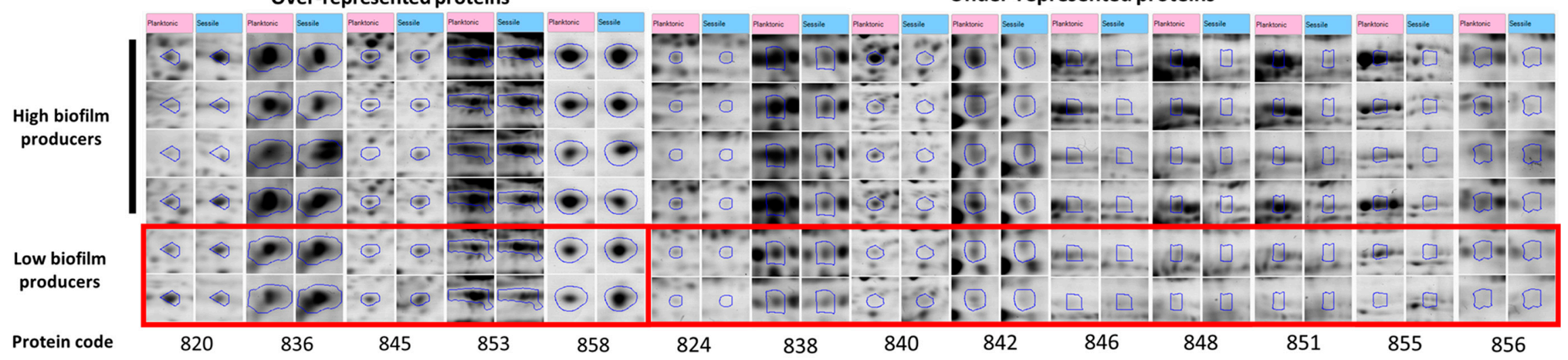

b

Over-represented biological function

Under-represented biological function
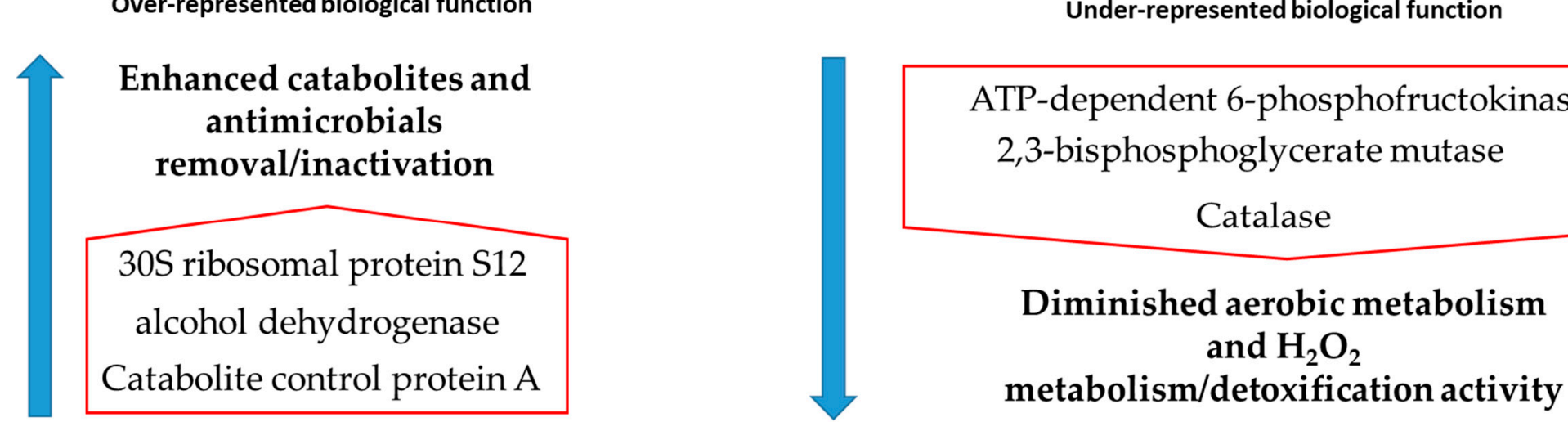

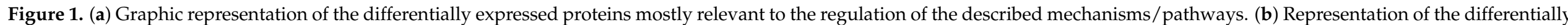
regulated proteins and the related modulated mechanisms. 


\section{Discussion}

Biofilms growth is the preferred strategy for the expansion and survival of many clinically and environmentally relevant microorganisms [5]. S. aureus is one well-known biofilm-forming pathogen capable of colonizing medical devices [26], food contact surfaces [21] and farm industry facilities [27]. In the biofilm form, S. aureus can successfully cope against strong stress conditions [28] and persist on the surfaces of food-processing plants [4], leading to recurrent contamination of both fresh and processed foods worldwide [29-32]. From this perspective, biofilm formation represents a severe threat because of its difficult removal linked to the extremely high tolerance to antimicrobials and antibiotics. Improving knowledge about its formation mechanisms and pathways is mandatory to better design possible and practical intervention strategies. Studies performed on single strains (strain-specific mechanisms) documented the over-representation of fibrinogen-binding protein and the accumulation-associated protein (Aap) in S. aureus cells growing embedded in the biofilm matrix in comparison to those growing in the planktonic form $[33,34]$. Also, increased production of staphylococcal accessory regulator A (SarA) was shown in biofilm formation [20].

All these and many other studies extensively describe the physiology of $S$. aureus biofilm formation that is specific to the strain analyzed. However, it is not considered that diverse $S$. aureus strains may have different mechanisms and pathways of biofilm formation.

In the current study, we employed a comparative proteomic approach to understand better the process of biofilm formation and the possible mechanisms involved in the enhancement of antimicrobial resistance. To achieve this result, we performed a differential proteomics analysis of planktonic versus sessile S. aureus isolates and ATCC strains. Six different strains with a wide range of biofilm formation indexes were employed in order to maximize the possibility to detect general mechanisms more representative of the S. aureus specie.

The whole comparison allowed the discovery of 14 proteins differentially regulated between the planktonic and sessile group and, three of those (alcohol dehydrogenase, ATP-dependent 6-phosphofructokinase and fructose-bisphosphate aldolase) were specific to the high biofilm-producing strains.

Ribosomal proteins are involved in biofilm regulation/formation and enhanced antimicrobial resistance $[35,36]$. Interestingly, changes at the ribosomal protein isoforms can shape the response to antibiotics by modifying the affinity of tetracyclines, chloramphenicol, macrolides (e.g., erythromycin) and aminoglycosides (e.g., streptomycin) for the transcription machinery. Hence, a switch in the composition of ribosomal subunits could be involved in biofilm formation and the different susceptibility to antimicrobial molecules [37].

Fructose bisphosphate aldolase and catabolite control protein A (ссрA) are overrepresented in the biofilm conformation versus the sessile condition. The first is an essential enzyme of the glycolytic pathway with virulence functions shaped according to its cellular localization (i.e., moonlighting properties) [38]. As a moonlight protein, it is often expressed in the bacterial surface [39] where it has been linked to virulence in several bacterial pathogens, such as Francisella [40], by directly affecting cell migration through its interference with the actin polymerization process.

Similarly, fructose bisphosphate aldolase expression is induced in oxygen depletion conditions, and it has also been associated with transcriptional regulator functions [39]. Catabolite control protein A (cсpA) was found to be massively over-represented in both high and low biofilm producers growing in the sessile conditions. This might be explained by the requirements of the typical multi-layered packed structure of the biofilm, which needs a tight control of nutrients availability, catabolites and secondary metabolites (e.g., ethanol, reactive oxygen species (ROS) etc.). Indeed, nutrients depletion or catabolites accu- 
mulation would exert toxic/detrimental effects on the bacterial community itself. In Gram+ bacteria, ccpA expression regulates the synthesis of capsular polysaccharides, toxigenic exoproteins and promotes biofilm formation [25]. Similarly, S. epidermidis biofilm formation is positively regulated by ccpA and causes tricarboxylic acid (TCA) cycle repression [41]. This demonstrates that the management of carbon and energy flow by regulating the enzymes involved in glycolytic/fermentative metabolism [42] represents an essential element for the proper formation of biofilm. Accordingly, previous evidence reported that environmental acidification or other phenomena associated with rapid metabolism of carbohydrates occurring in bacteria growing in sessile conditions are regulated by cсpA throughout the modulation of pfka and gpma expression [42,43]. Moreover, the structural organization of the biofilm is likely to result in the accumulation of toxic secondary metabolites such as ethanol from fermentation processes. This may explain the detected increased expression of alcohol dehydrogenase (adh) in the sessile growing strains. The oxygen depletion in the biofilm's inner layers may cause a metabolic shift towards the mixed alcoholic fermentation with increased ethanol concentration that needs to be promptly detoxified by the induction of adh [44-46]. The hypothesis of the metabolic shift towards fermentation and ethanol production is also supported by the under-expression of PfkA and gpmA, which are active in pyruvate production. By limiting the production of pyruvate, sessile cells control the pathways towards any possible fermentative process. Thus, the reduced abundance of PfkA and gpmA in the sessile bacteria might represent the effect of a negative feedback modulation of the fermentative process to protect the bacteria from the toxicity of their secondary metabolites. Analogously, the reduced abundance of catalase, the enzyme active in ROS detoxification, may be a consequence of the reduced oxygen availability in the bacterial samples growing in biofilm form [47]. Such a reduction in the hydroperoxide detoxification power is confirmed by the down-regulation of 3 different catalase isoforms and of alkyl hydroperoxide reductase subunit C (Q2FJN4). This may help to explain the high power of low doses of hydrogen peroxide to dissolve the biofilm conformation [48].

\section{Conclusions}

The comparative top-down proteomics (2D-electrophoresis-MALDI TOF) approach used here identified some possible biofilm formation mechanisms of $S$. aureus strains with a wide range of biofilm formation indexes. Biofilm is one of the essential strategies for bacterial virulence and persistence over a wide variety of surfaces and unfavourable conditions and it facilitates survival and resistance in the presence of antimicrobial compounds [49]. Comparison of high- and low-biofilm forming strains in sessile and planktonic form highlighted common mechanisms as the catabolite control and the modulation of the detoxification machinery aimed at avoiding self-inhibition/toxicity (i.e., ethanol detoxification). Glycolysis and aerobic metabolisms seem to be down-regulated in favor of possible fermentation pathways that might be responsible for ethanol production and, possibly, for the induction of alcohol dehydrogenase production.

This study is characterized by using a top-down proteomics approach that led the differential quantification of intact proteofoms. On the other hand, this approach limits the detection of differentially represented, less-abundant proteins. Complementing these data with shotgun proteomics and metabolomics is desired to support the observed evidence and to discover potential biomolecular targets to contrast and/or attenuate this phenomenon.

Supplementary Materials: The following are available online at https:/ /www.mdpi.com/article/10 .3390/ani11040966/s1, Table S1: Raw normalized volume.

Author Contributions: Conceptualization, C.P., P.A.D.C., A.S., P.R.; Data curation, C.P., P.A.D.C., A.S., V.G.; Formal analysis, C.P., P.A.D.C., A.S., V.G.; Funding acquisition, A.I., L.B., A.U., P.R.; Investigation, C.P., P.A.D.C., A.S., V.G., B.T.; Methodology, C.P., P.A.D.C., A.S., V.G., P.R., Project administration, A.I., P.R.; Resources, A.I., P.R., L.B., A.U.; Writing-original draft, C.P., P.A.D.C., A.S., P.R.; Writing-review and editing, C.P., P.A.D.C., A.S., V.G., B.T., N.C., C.C., A.I., P.R. All authors have read and agreed to the published version of the manuscript. 
Funding: This research received no external funding.

Institutional Review Board Statement: Not applicable.

Data Availability Statement: Not applicable.

Conflicts of Interest: The authors declare no conflict of interest.

\section{References}

1. Oniciuc, E.-A.; Likotrafiti, E.; Alvarez-Molina, A.; Prieto, M.; López, M.; Alvarez-Ordóñez, A. Food processing as a risk factor for antimicrobial resistance spread along the food chain. Curr. Opin. Food Sci. 2019, 30, 21-26. [CrossRef]

2. Guardabassi, L.; Larsen, J.; Weese, J.; Butaye, P.; Battisti, A.; Kluytmans, J.; Lloyd, D.; Skov, R. Public health impact and antimicrobial selection of meticillin-resistant staphylococci in animals. J. Glob. Antimicrob. Resist. 2013, 1, 55-62. [CrossRef]

3. Weese, J.S.; van Duijkeren, E. Methicillin-resistant Staphylococcus aureus and Staphylococcus pseudintermedius in veterinary medicine. Vet. Microbiol. 2010, 140, 418-429. [CrossRef]

4. Herrera, J.J.R.; Cabo, M.L.; González, A.; Pazos, I.; Pastoriza, L. Adhesion and detachment kinetics of several strains of Staphylococcus aureus subsp. aureus under three different experimental conditions. Food Microbiol. 2007, 24, 585-591. [CrossRef]

5. Donlan, R.M.; Costerton, J.W. Biofilms: Survival mechanisms of clinically relevant microorganisms. Clin. Microbiol. Rev. 2002, 15, 167-193. [CrossRef]

6. Sauer, K.; Camper, A.K.; Ehrlich, G.D.; Costerton, J.W.; Davies, D.G. Pseudomonas aeruginosa displays multiple phenotypes during development as a biofilm. J. Bacteriol. 2002, 184, 1140-1154. [CrossRef]

7. Resch, A.; Rosenstein, R.; Nerz, C.; Götz, F. Differential gene expression profiling of Staphylococcus aureus cultivated under biofilm and planktonic conditions. Appl. Environ. Microbiol. 2005, 71, 2663-2676. [CrossRef]

8. Costerton, J.W.; Stewart, P.S.; Greenberg, E.P. Bacterial biofilms: A common cause of persistent infections. Science 1999, 284, 1318-1322. [CrossRef]

9. Brooks, J.D.; Flint, S.H. Biofilms in the food industry: Problems and potential solutions. Int. J. Food Sci. Technol. 2008, 43, 2163-2176. [CrossRef]

10. Srey, S.; Jahid, I.K.; Ha, S.-D. Biofilm formation in food industries: A food safety concern. Food Control 2013, 31, 572-585. [CrossRef]

11. Wassenaar, T.; Ussery, D.; Nielsen, L.; Ingmer, H. Review and phylogenetic analysis of qac genes that reduce susceptibility to quaternary ammonium compounds in Staphylococcus species. Eur. J. Microbiol. Immunol. 2015, 5, 44-61. [CrossRef]

12. Glinel, K.; Thebault, P.; Humblot, V.; Pradier, C.-M.; Jouenne, T. Antibacterial surfaces developed from bio-inspired approaches. Acta Biomater. 2012, 8, 1670-1684. [CrossRef]

13. Simoes, M.; Simões, L.C.; Vieira, M.J. A review of current and emergent biofilm control strategies. LWT Food Sci. Technol. 2010, 43, 573-583. [CrossRef]

14. Mah, T.-F.C.; O'Toole, G.A. Mechanisms of biofilm resistance to antimicrobial agents. Trends Microbiol. 2001, 9, 34-39. [CrossRef]

15. Branda, S.S.; Vik, Å.; Friedman, L.; Kolter, R. Biofilms: The matrix revisited. Trends Microbiol. 2005, 13, 20-26. [CrossRef]

16. Flemming, H.-C.; Wingender, H.-C.F.J.; Szewzyk, U.; Steinberg, P.; Rice, S.A.; Kjelleberg, S.A.R.S. Biofilms: An emergent form of bacterial life. Nat. Rev. Microbiol. 2016, 14, 563. [CrossRef] [PubMed]

17. Das, S.; Vishakha, K.; Banerjee, S.; Mondal, S.; Ganguli, A. Sodium alginate-based edible coating containing nanoemulsion of Citrus sinensis essential oil eradicates planktonic and sessile cells of food-borne pathogens and increased quality attributes of tomatoes. Int. J. Biol. Macromol. 2020, 162, 1770-1779. [CrossRef] [PubMed]

18. Atshan, S.S.; Shamsudin, M.N.; Esekawi, Z.; Lung, L.T.T.; Talab, F.B.; Liew, Y.K.; Alreshidi, M.A.; Abduljaleel, S.A.; Hamat, R.A. Comparative proteomic analysis of extracellular proteins expressed by various clonal types of Staphylococcus aureus and during planktonic growth and biofilm development. Front. Microbiol. 2015, 6, 524. [CrossRef]

19. Bénard, L.; Litzler, P.Y.; Cosette, P.; Lemeland, J.F.; Jouenne, T.; Junter, G.A. Proteomic analysis of Staphylococcus aureus biofilms grown in vitro on mechanical heart valve leaflets. J. Biomed. Mater. Res. Part A An Off. J. Soc. Biomater. Japanese Soc. Biomater. Aust. Soc. Biomater. Korean Soc. Biomater. 2009, 88, 1069-1078.

20. Resch, A.; Leicht, S.; Saric, M.; Pásztor, L.; Jakob, A.; Götz, F.; Nordheim, A. Comparative proteome analysis of Staphylococcus aureus biofilm and planktonic cells and correlation with transcriptome profiling. Proteomics 2006, 6, 1867-1877. [CrossRef]

21. Di Ciccio, P.; Vergara, A.; Festino, A.; Paludi, D.; Zanardi, E.; Ghidini, S.; Ianieri, A. Biofilm formation by Staphylococcus aureus on food contact surfaces: Relationship with temperature and cell surface hydrophobicity. Food Control 2015, 50, 930-936. [CrossRef]

22. Soggiu, A.; Piras, C.; Greco, V.; Devoto, P.; Urbani, A.; Calzetta, L.; Bortolato, M.; Roncada, P. Exploring the neural mechanisms of finasteride: A proteomic analysis in the nucleus accumbens. Psychoneuroendocrinology 2016, 74, 387-396. [CrossRef] [PubMed]

23. Piras, C.; Soggiu, A.; Bonizzi, L.; Greco, V.; Ricchi, M.; Arrigoni, N.; Bassols, A.; Urbani, A.; Roncada, P. Identification of immunoreactive proteins of Mycobacterium avium subsp. paratuberculosis. Proteomics 2015, 15, 813-823. [CrossRef]

24. Cramton, S.E.; Gerke, C.; Schnell, N.F.; Nichols, W.W.; Götz, F. The intercellular adhesion (ica) locus is present in Staphylococcus aureus and is required for biofilm formation. Infect. Immun. 1999, 67, 5427-5433. [CrossRef]

25. Seidl, K.; Goerke, C.; Wolz, C.; Mack, D.; Berger-Bächi, B.; Bischoff, M. Staphylococcus aureus CcpA affects biofilm formation. Infect. Immun. 2008, 76, 2044-2050. [CrossRef] [PubMed]

26. Ziebuhr, W. Staphylococcus aureus and Staphylococcus epidermidis: Emerging pathogens in nosocomial infections. Contrib. Microbiol. 2001, 8, 102-107. 
27. Weber, M.; Liedtke, J.; Plattes, S.; Lipski, A. Bacterial community composition of biofilms in milking machines of two dairy farms assessed by a combination of culture-dependent and-independent methods. PLoS ONE 2019, 14, e0222238. [CrossRef]

28. Enright, M.C. The evolution of a resistant pathogen-the case of MRSA. Curr. Opin. Pharmacol. 2003, 3, 474-479. [CrossRef]

29. Nostro, A.; Blanco, A.R.; Cannatelli, M.A.; Enea, V.; Flamini, G.; Morelli, I.; Roccaro, A.S.; Alonzo, V. Susceptibility of methicillinresistant staphylococci to oregano essential oil, carvacrol and thymol. FEMS Microbiol. Lett. 2004, 230, 191-195. [CrossRef]

30. Braga, L.C.; Shupp, J.; Cummings, C.; Jett, M.; Takahashi, J.; Carmo, L.; Chartone-Souza, E.; Nascimento, A. Pomegranate extract inhibits Staphylococcus aureus growth and subsequent enterotoxin production. J. Ethnopharmacol. 2005, 96, 335-339. [CrossRef]

31. Marques, S.C.; Rezende, J.D.G.O.S.; Alves, L.A.D.F.; Silva, B.C.; Alves, E.; De Abreu, L.R.; Píccoli, R.H. Formation of biofilms by Staphylococcus aureus on stainless steel and glass surfaces and its resistance to some selected chemical sanitizers. Braz. J. Microbiol. 2007, 38, 538-543. [CrossRef]

32. Oulahal, N.; Brice, W.; Martial, A.; Degraeve, P. Quantitative analysis of survival of Staphylococcus aureus or Listeria innocua on two types of surfaces: Polypropylene and stainless steel in contact with three different dairy products. Food Control 2008, 19, 178-185. [CrossRef]

33. Wolf, C.; Hochgräfe, F.; Kusch, H.; Albrecht, D.; Hecker, M.; Engelmann, S. Proteomic analysis of antioxidant strategies of Staphylococcus aureus: Diverse responses to different oxidants. Proteomics 2008, 8, 3139-3153. [CrossRef]

34. Engelmann, S.; Hecker, M. Proteomic analysis to investigate regulatory networks in Staphylococcus aureus. In Bacterial Pathogenesis; Springer: Berlin/Heidelberg, Germany, 2008; pp. 25-45.

35. Sałamaszyńska-Guz, A.; Rose, S.; Lykkebo, C.A.; Taciak, B.; Bącal, P.; Uśpieński, T.; Douthwaite, S. Biofilm formation and motility are promoted by Cj0588-directed methylation of rRNA in Campylobacter jejuni. Front. Cell. Infect. Microbiol. 2018, 7, 533. [CrossRef] [PubMed]

36. Zheng, J.; Wu, Y.; Lin, Z.; Wang, G.; Jiang, S.; Sun, X.; Tu, H.; Yu, Z.; Qu, D. ClpP participates in stress tolerance, biofilm formation, antimicrobial tolerance, and virulence of Enterococcus faecalis. BMC Microbiol. 2020, 20, 30. [CrossRef]

37. Lilleorg, S.; Reier, K.; Volõnkin, P.; Remme, J.; Liiv, A. Phenotypic effects of paralogous ribosomal proteins bL31A and bL31B in E. coli. Sci. Rep. 2020, 10, 1-10. [CrossRef]

38. Shams, F.; Oldfield, N.J.; Wooldridge, K.G.; Turner, D.P.J. Fructose-1, 6-bisphosphate aldolase (FBA)—A conserved glycolytic enzyme with virulence functions in bacteria: 'Ill met by moonlight'. Biochem. Soc. Trans. 2014, 42, 1792-1795. [CrossRef] [PubMed]

39. Oldfield, N.J.; Shams, F.; Wooldridge, K.G.; Turner, D.P.J. Moonlighting Functions of Bacterial Fructose 1, 6-Bisphosphate Aldolases. In Moonlighting Proteins: Novel Virulence Factors in Bacterial Infections; John Wiley \& Sons, Inc.: Hoboken, NJ, USA, 2017; pp. 321-331.

40. Ziveri, J.; Tros, F.; Guerrera, I.C.; Chhuon, C.; Audry, M.; Dupuis, M.; Barel, M.; Korniotis, S.; Fillatreau, S.; Gales, L.; et al. The metabolic enzyme fructose-1, 6-bisphosphate aldolase acts as a transcriptional regulator in pathogenic Francisella. Nat. Commun. 2017, 8, 1-15. [CrossRef]

41. Sadykov, M.R.; Hartmann, T.; Mattes, T.A.; Hiatt, M.; Jann, N.J.; Zhu, Y.; Ledala, N.; Landmann, R.; Herrmann, M.; Rohde, H.; et al. CcpA coordinates central metabolism and biofilm formation in Staphylococcus epidermidis. Microbiology 2011, 157, 3458. [CrossRef]

42. Rudra, P.; Boyd, J.M. Metabolic control of virulence factor production in Staphylococcus aureus. Curr. Opin. Microbiol. 2020, 55, 81-87. [CrossRef]

43. Kim, J.N.; Burne, R.A. CcpA and CodY coordinate acetate metabolism in Streptococcus mutans. Appl. Environ. Microbiol. $2017,83$. [CrossRef] [PubMed]

44. Fuchs, S.; Pané-Farré, J.; Kohler, C.; Hecker, M.; Engelmann, S. Anaerobic gene expression in Staphylococcus aureus. J. Bacteriol. 2007, 189, 4275-4289. [CrossRef] [PubMed]

45. Becker, P.; Hufnagle, W.; Peters, G.; Herrmann, M. Detection of differential gene expression in biofilm-forming versus planktonic populations of Staphylococcus aureus using micro-representational-difference analysis. Appl. Environ. Microbiol. 2001, 67, 2958-2965. [CrossRef] [PubMed]

46. Zhang, K.; Yang, X.; Yang, J.; Qiao, X.; Li, F.; Liu, X.; Wei, J.; Wang, L. Alcohol dehydrogenase modulates quorum sensing in biofilm formations of Acinetobacter baumannii. Microb. Pathog. 2020, 148, 104451. [CrossRef]

47. Shen, F.; Ge, C.; Yuan, P. Metabolomics Study Reveals Inhibition and Metabolic Dysregulation in Staphylococcus aureus Planktonic Cells and Biofilms Induced by Carnosol. Front. Microbiol. 2020, 11, 2315. [CrossRef]

48. Christensen, B.E.; Trønnes, H.N.; Vollan, K.; Smidsrød, O.; Bakke, R. Biofilm removal by low concentrations of hydrogen peroxide. Biofouling 1990, 2, 165-175. [CrossRef]

49. Vázquez-Sánchez, D.; Rodríguez-López, P. Biofilm formation of Staphylococcus aureus. In Staphylococcus aureus; Elsevier: Amsterdam, The Netherlands, 2018; pp. 87-103. 